\title{
Parallaxes as Means of Organizing Memory in Travel Narratives of Patrick Leigh Fermor and Ryszard Kapuściński
}

\begin{abstract}
This paper offers a comparative analysis of travel narratives of two key contemporary writers: Patrick Leigh Fermor and Ryszard Kapuściński. Fermor's A Time of Gifts: On Foot to Constantinople; From the Hook of Holland to the Middle Danube (1977), Between the Woods and the Water (1986), and The Broken Road (2015) are compared with Kapuściński's: Imperium (1993), The Shadow of the Sun (1998), and Travels with Herodotus (2007). The figure of a 'parallax' is suggested as being crucial in capturing the key similarities between Fermor's and Kapuściński's travel narratives. The differences between these narratives are explained in terms of the differences in developments of Anglophone and Polish travel writing traditions.
\end{abstract}

Keywords: travel writing, genre, parallax, Ryszard Kapuściński, Patrick Leigh Fermor.

Travel writing (podróżopisarstwo in Polish) is often regarded as a supra-generic category combining all types of texts fictional and non-fictional, narrative and non-narrative, versed and nonversed, of which the main theme is travel (See, for example, Borm 2004: 13-17, Witosz 2007: 11-28). At the centre of the travel writing tradition, both in Anglophone literatures and Polish literature, there exists a referential genre predominantly narrated in the first person and predominantly nonfictional which is known as the travel book (or travelogue) in English and reportaż podróżniczy in Polish. Ian Borm's (2004: 17) definition states that the travel book is: "any narrative characterized by a non-fiction dominant that relates (almost always) in the first person a journey or journeys that the reader supposes to have taken place in reality while assuming or presupposing that author, narrator and principal character are but one or identical." Traditionally, both these genres, of travel book and reportaż podróżniczy, have relied on a retrospective type of narration making both travel books and reportá̇ podróżniczy formally similar to journals and/or diaries. From the perspective of most travel books and most reportaż podróżniczy written over the last two centuries, the minor differences which the historians and theoreticians of life narratives postulate to exist between journals and diaries (See, for example, Smith and Watson 2001: 193-196) are of no consequence from the perspective adopted in this paper. It is also of little consequence to what ex- 
tent the final version has followed some regularly kept diary or has diverged from it through subsequent re-writing (See Forsdick et al. 2006: 24). Most travel books and reportaż podróżniczy are linear, retrospective narratives, usually following the tripartite pattern: of departure, the journey itself, and return. And in most cases, the retrospection does not go back very far, usually extending to a few months, a year or a couple of years at the most. Most travel writers (and particularly professional travel writers) write their travel accounts and publish their travel books swiftly after the journey's end; although some 'artistic' travel books take much longer to complete. Two famous British travel books which followed the journal/diary textualization process described above but took much longer are Alexander Kinglake's Eothen (1844) and Robert Byron's The Road to Oxiana (1937). As Jonathan Raban, himself both a major travel writer and a critic, wrote in his Preface to Eothen: "The book took Kinglake a decade to write. It was revised and re-revised; its style of bright talk was the product of a long process of literary refinement." (Raban 1982: v) A similar method of rigorous revisions and re-writings administered on the text till it acquired the varnish of apparent off-handed spontaneity was performed nine decades later by Robert Byron.

Although predominant, travel books and reportaże podróżnicze following relatively closely in the wake of the real journey, are not the only ways of textualizing journeys. There exists an approach that, from the perspective of life narratives' taxonomy, is much more similar to that of a memoir than of either a diary or a journal. I would like to argue that this type of narrating travel can be best metaphorically captured through the figure of a 'parallax', and that three travel books, each of two very prominent travel book writers, one British and one Polish, reveal striking similarities, particularly when seen through the lens of a memoir-like type of focalization of the past, where memory is used in a much less mimetic and much more creative ways than in the bulk of travel writing. I will apply the figure of 'parallax' to three travel books by Patrick Leigh Fermor (1915-2011): A Time of Gifts: On Foot to Constantinople; From the Hook of Holland to the Middle Danube (1977), Between the Woods and the Water (1986), and The Broken Road (2015).

According to Artemis Cooper (2012: 325), the biographer of Patrick Leigh Fermor, in 1966 Fermor nursed the idea of giving the title of Parallax to the book he was working on at that time. Most often used in astronomy, the word alludes to the difference in the appearance of an object seen from two different angles. It seemed a good way to draw attention to the gap between the nineteen-year-old walker and the forty-nine-year-old writer. The initial enthusiasm did not last long, though; Fermor got stuck while writing Parallax and abandoned the project. He returned to it in the early 1970s and worked laboriously on it until 1977, when the book finally appeared. However, parallex, as the title of the first book to describe Fermor's walk across Europe, was replaced by an intertextual, nostalgic quote from a poem written by Louise MacNeice, Twelfth Night: "For now that the time of gifts is gone...". A Time of Gifts, was very appropriate for the 'winter journey' of a boy of eighteen through the Europe of 1934, described it from the perspective of a man who was passed sixty when the book finally appeared: "For now that the time of gifts is gone--/ O boys that grow, O snows that melt, / O bathos that the years must fill--/ Here is dull earth to build upon/ Undecorated; we have reached/ Twelfth Night or what you will... you will". As we can see for 
ourselves, MacNeice's poem “Twelfth Night” leads directly to more intertexts, the most obvious of which is Shakespeare's play “Twelfth Night”, bringing with it evocations of Christmases long past, celebrated with traditional medieval gusto, from the first day of Christmas to the twelfth day (and night) of Christmas, the Eve of the Epiphany, celebrated on January 6. As Artemis Cooper (2012: 325-331) explained, it was Fermor's friend and editor John (Jock) Murray who was not happy with the learned title Parallax, and insisted on its change to a title more commercially oriented. I am convinced that 'parallax', abandoned by Fermor and Murray, can nevertheless serve very well as a metaphor as well as a synecdoche for a kind of travel narrative in which the narrator, an experienced traveler, contrasts his/her experienced persona with himself/herself at the beginning of his mind-transforming wanderings.

Patrick Leigh Fermor, after his 'Great Trudge' (as he later referred to his venture) on foot across Europe, from the Hook of Holland to Constantinople (as he, in his heliophilia, insisted on calling Istanbul), undertaken between December 1933 and 1 January 1935, stayed in the Balkans, where he learnt the languages and enjoyed life. When World War II broke out he went to Britain to volunteer. He served with the Special Operations Executive in Crete, occupied by the Germans. He distinguished himself by masterminding and carrying out the kidnapping of German general Heinrich Kreipe, the regional commander of the island, whom Fermor managed to lead all the way through the mountains of Crete to a boat on the southern coast which took them to Alexandria (occupied by the British at that time). Fermor alluded to these events in A Time of Gifts, mostly in the intertext of an introductory letter opening this travel book, addressed to a great wartime friend and fellow SOE officer, Xan Fielding.

After the war Fermor led a wandering life and gradually established his reputation (mostly) as a travel writer. His first travel book, The Traveller's Tree, which was published in 1950, was a classical travel narrative recounting his travels (with a group of friends) in the West Indies in 19471948. Fermor's growing sentiment for his adopted patria of Greece led to prolonged wanderings in all different nooks and crannies of continental Greece. In 1961, with his wife Joan, he bought a plot of land in the remote village of Kardamyli on the Peloponnese coast, and there they built a comfortable house in a quiet bay (to Fermor's own design). Two travel books from this period described the extensive travels which Fermor with his wife undertook in Greece: Mani: Travels in the Southern Peloponnese (1958) and Roumeli: Travels in Northern Greece (1966). It was the extended research on Greek civilization, ancient and modern, which led to the writing of these two travel books. The narrative persona of both of them may be placed within the category of 'a gentleman scholar', more typical in the British travel writing of the nineteenth century, and very rare in the twentieth, where the narrative persona is foregrounded as an amateur scholar, expert in the areas of knowledge of his own choice. In Patrick Leigh Fermor's Mani and Roumeli this expertise is extended into such areas as: the Hellenic past, its literature and language, the Byzantine history of art, the history of Greece under Ottoman rule, and the history of modern Greece. The Greeks the Fermors meet during their wanderings are described with love, care, warmth and humour, while the strata of the past and customs are laboriously revealed in the erudite narration. 
Mani and Roumeli are distinguished by their passionate erudition, but their structures resemble those of other British travel books, when the 'scholarship' of the narrator is allowed to be the centre of focalization: thus the chronologically described wanderings are interspersed with learned essays devoted to specific aspects of Greek history and culture. At times these essays verge on the poetic, fantastic and/or bizarre. For example, there is a passage in chapter three of Mani, entitled Kardamyli: Byzantium Restored, when Fermor describes a visit to the hut of the Mani fisherman, Estavrios Mourzinos, who is reputed by local hearsay to be the last descendent of the Byzantine emperors. Estavrios behaves humbly and appropriately:

"That's what they say," he said, "but we don't know anything about it. They are just old stories..." He poured out hospitable glasses of ouzo, and the conversation switched to the difficulties of finding a market for fish, there was so much competition. There is a special delight in this early morning drinking in Greece. (Fermor 2006: 41)

With his skilful novelistic narration, utilizing free indirect speech stressing the banal, everyday topic, the conversation quickly switches to "difficulties of finding a market for fish, there was so much competition", with the delight of the persona in such conversations and situations, especially as they are carried out ornamented with the customary drinking of a strong local liquor, ouzo, even though it is an early-morning visit. Spurred on by ouzo, the narrative persona's imagination is allowed to run high and wild. The fragment which follows reads:

Old stories indeed. But supposing every link were verified, each skaky detail proved. Supposing this modest and distinguished looking fisherman were really heir of the Paleologi, descendant of Constantine $\mathrm{XI}$ and Michael VIII the Liberator, successor to Alexis Comnène and Basil the Bulgar-Slayer and Leo the Isaurian and Justinian and Theodosius and St. Constantine the Great? And, for that matter, to Diocletian and Heliogabalus and Marcus Aurelius, to the Antonines, the Flavians, the Claudians and the Julians, all the way back to the Throne of Augustus Caesar on the Palatine, where Romulus had laid the earliest foundations of Rome?...The generous strength of the second glass of ouzo accelerated these cogitations. (Fermor 2006: 44).

We do get something of a minor parallax here. Long before A Time of Gifts, there is a hiatus in perspective between the sober (in both senses of the word) narrative persona describing an early morning visit to the hut of a hospitable fisherman and the figure of Fermor-traveller, fascinated by Greece's ancient heritage, discernable (even if only through an ouzo-inspired flight of fancy) in modern Greece's remote villages, willingly succumbing to a chat with the fisherman, who has turned out (even if only in the narrator's fancy) to be a true descendent of Byzantine emperors. Fermor makes fun of the extended search for documents to demonstrate the imperial lineage all over the post-Byzantine world, and gets even more involved in this vision:

Envoys returned empty-handed from Barbados and the London docks... Some Russian families allied to Ivan the Terrible and the Palaelogue Princess Anastasia Tzarogorodskaja had to be considered... Then all 
at once a new casket of documents came to light and a foreign emissary was despatched hot foot to the Peloponnese, over the Taygetus to the forgotten hamlet of Kardamyli... By now all doubt had vanished. The Emperor Eustrarius leant forward to refill the glasses with ouzo for the fifth time. The Basilissa shooed away a speckled hen which had wandered indoors after the crumbs. On a sunny doorstep, stroking a marmalade cat, sat the small Diadoch and Despot of Mitra. (Fermor 2006: 45-46)

It all leads to the description of the coronation of Eustrarius, the Emperor-Fisherman, and the splendours and glories of the city of Byzantium re-created in a vision, at the same time tongue-incheek and overpowering:

Constantinople appeared beyond our bows, its towers and bastions glittering, its countless domes and cupolas bubbling among pinnacles and dark sheaves of cypresses, all of them climbing to the single great dome topped with the flashing cross that Constantine has seen in a vision on the Milvian bridge. There, by the Golden Gate, in the heart of the mighty concourse, waited the lords of Byzantium; the lesser Caesars and Despots and Sebastrocrators, the Grand Logethete in his globular headgear, the Counts of the Palace, the Sword Bearer, the Chartophylax, the Great Duke, the thalassocrats and polemarchs, the Strateges of the Cretan archers, of the hoplites and the peltasts, and the cataphracts, the Silentiaries, the Count of the Excubitors, the governors of the Avian Themes, the Clissourarchs, the Grand Eunuch and (for by now all Byzantine history had melted into a single anachronistic maelstrom) the Prefects of Sicily and Nubia and Ethiopia and Egypt and Armenis... (Fermor 2006: 46-47)

"An anachronistic maelstrom" continues for a few more pages with verbal virtuosity, combining historical names with linguistic fireworks, interspersed with the fisherman's cliffhanging gale story. The ending of the chapter is once again realistic:

The bottle was empty... The schoolmaster's shadow darkened the doorway. "You'd better hurry," he said. "The caique for Acropolis is just leaving." We all rose to our feet, upsetting in our farawells, a basket of freshly cut bait and a couple of tridents which fell to the floor with a clatter. We stepped out into the sobering glare of noon. (Fermor 2006: 50)

I have quoted just some selected passages from the third chapter of Mani, hoping to show the lavishness of Fermor's style, the depth of his research and the intensity of his love of Greece and Greeks. It took Fermor even longer to polish the fragments of Parallax, which was to be transformed into the masterpiece A Time of Gifts. I believe that his laborious method of numerous corrections and ever new renditions of individual fragments can be compared with one major novelist and master-stylist of the English language: James Joyce, who spent seven years on Ulysses (1914-1921) and fifteen on Finnegan's Wake (1924-1939).

As alluded to before, the 'parallax effect', so central to A Time of Gifts, the dramatic and nostalgic power of the book, lies to a large extent in these shifts of perspectives between the two figures of Patrick Leigh Fermor. One, a boy of seventeen, a drop out from a series of public schools, living on the fringe of the bohemian world of London and inspired by Robert Byron, a young travel writer and a great enthusiast of the 'Byzantine Achievement' (which he described in the travel book The Station (1928), about his visit to the art treasures of the Holy Mountain of Athos) at the begin- 
ning of December 1933, on board a small trade vessel sails from London to the Hook of Holland; hoping to walk all the way across Europe to Constantinople with a small backpack filled with some clothes, a notebook and a copy of the Oxford Book of Verse. The other figure it the narrative persona of A Time of Gifts, a middle-aged travel writer who over the four decades that have passed since his 'Great Trudge' has accumulated the wealth of experiences and erudition.

In A Time of Gifts the final success was achieved by Fermor not only thanks to great care with the poetic, often nostalgic use of English, although this was the feature of the book that was most often discussed by reviewers, but also thanks to a very elaborate combination and intermingling of such disparate elements as: sophisticated intertextuality and the great concern for a harmonious union between the text proper and various paratexts and intertexts (On the importance of paratexts in A Time of Gifts, see Moroz 2016).

Poetry as an intertext (and a metatext) joining the two 'parallaxed' aspects of Fermor, aged seventeen and forty-nine, is given a crucial role, starting from the three carefully selected epigraphsparatexts opening the book. One, as mentioned before, comes from a poem by Louis MacNeice "Twelfth Night". One comes from the metaphysical poet George Herbert and reads: "I struck the board and cry'd 'No more/ I will abroad.' What, shall I ever sigh and pine?/ My life and lines are free; free as the road, Loose as the wind." And one is given in the Latin original and comes from a poem by Titus Petronius Arbiter

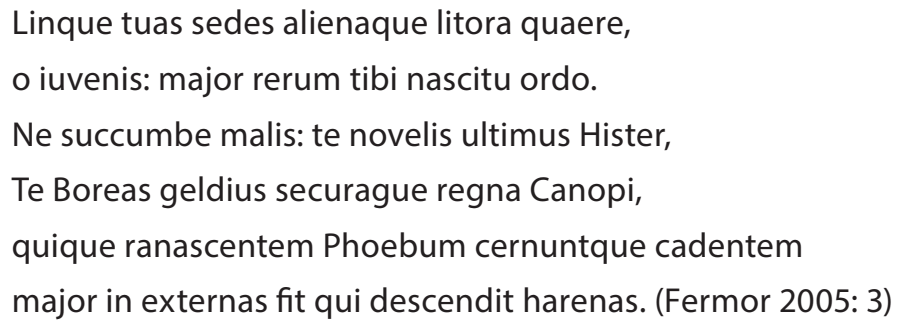

Similarly to the other two English epigraphs, it is carefully selected, both for its poetic power and appropriateness for the parallax metaphor employed in A Time of Gifts. In Petronius's poem the young Fermor of 1933 ("o juvenis") is directly asked (be an experienced poet) to embark on a journey to the "ultimus Hister",that is the far-off Danube (the Latin name for the "Danube" was the "Hister") with the promise that "the greater succession of events" ("major rerum") will happen on the way. And, in fact, by the end of A Time of Gifts young Fermor is described as he reaches Esztergom, an ancient Hungarian town on the Danube.

At a crucial moment, the narrative personae's expertise in poetry ancient and modern, with the love of poetry of the young Fermor, aged seventeen, carefully described at the beginning with just one crucial book, the Oxford Book of Verse in his rucksack, are allowed to merge with the aspect of a persona (only rarely alluded to in A Time of Gifts) as a war-hero, thus 'enlarging' the parallax to three, rather than two perspectives. It happens when the narrative persona describes the poets and poems which influenced his younger alter ego. When he moves on to Roman poetry, he mentions Lucan, Catullus, Virgil and Horace, and adds that he taught himself "a number of the Odes" 
by Horace "and translated a few of them into awkward English sapphics and alcaics. Apart from their other charms, they were infallible mood-changers" (Fermor 2005: 85). And it is in this very moment that Fermor opens the parenthesis to tell this crucial story, adding this third, war-time, perspective:

One of them[odes, G.M] — ix. Ad Thaliarchum - came to my rescue in strange circumstances a few years later. The hazards of war landed me among the crags of occupied Crete with a band of Cretan guerillas and a captive German general whom we had waylaid and carried off into the mountains three days before. The German garrison of the island were in hot, but luckily temporarily misdirected, chase. It was a time of anxiety and danger: and for our captive, of hardship and distress. During a lull in the pursuit, we woke among the rocks just as a brilliant dawn was breaking over the crest of Mount Ida. We had been toiling over it, through snow and then rain, for the last two days. Looking across the valley at this flashing mountain-crest, the general murmured to himself:

Vides ut alta stet nive candidum

Soracte... (See how the deep snow shines on Mount Soracte!)

It was one of the ones I knew! I continued from where he had broken off:

... nec jam sustineat onus

Silvae laborantes geluque

Flumina constiterint acuto,

(The toiling woods can bear the load no longer, and the streams stand still in the sharp ice.)

and so on, through the remaining five stanzas to the end. The general's blue eyes had swivelled away from the mountain-top to mine-and when I'd finished, after a long silence, he said: "Ach so, Herr Major!" It was very strange. As though, for a long moment the war had ceased to exist. We had both drunk at the same fountains long before; and things were different between us for the rest of our time together. (Fermor 2005: 85-86)

It is difficult to assess to what extent this scene was 'constructed' or 're-constructed' from Fermor's war memories. Definitely, Patrick Leigh Fermor, with a group of Cretan partisans, abducted General Kreipe and took him, across the Cretan mountains, to a little bay in the south from which they were picked up by a motor-boat and transported to Alexandria. And Fermor and General Kreipe definitely met on a friendly footing in a 1972 TV programme on the general's abduction (Mastorakis 1972). One may hope that the fact of "drinking from the same fountain" was instrumental in arranging this meeting. The exact moment of the mutual recitation of Ad Thaliarchum and details of the scenery may just as well be elements of travel-writer's licencia poetica, after all the travel book as a genre, according to Borm (2004), is described as a genre of "non-fictional dominant" (Borm 2004: 17), which means, that although it is predominantly "non-fictional", "nonfictionality" is only a "dominant", not an "absolute rule", and travel writers feel free to construct scenes and conversations with the focus not so much on "re-constructing" the past from memories, as of "constructing" the dramatic, fictionalized versions of memories. And the quoted fragment describing the recitation of Horace's ode, introduced parenthetically (in a seemingly casual, off-hand manner) may be viewed, I think, as a high point in Fermor's application of the figure of parallax in travel writing. 
For reasons probably both literary and mental, the books on parallax and the 'Great Trudge' proved most difficult for Fermor to write. It took him almost a decade to complete the second book Between the Woods and the Water (it was finally published only in 1986), and the third and final book was published only posthumously in 2013 (it was edited by Fermor's biographer Artemis Cooper and a friend of his, the renowned travel writer Colin Thubron, for although Fermor had been working on it on and off for the last two decades of his life, it still had to be extensively edited before final publication).

While looking at three late travel books written by Ryszard Kapuściński Imperium, The Shadow of the Suns and Travels with Herodotus I would like to continue to rely on this powerful metaphor of parallax, which has been used to present Fermor's trilogy of the 'Great Trudge', and which can also be detected in Kapuściński's late work; to look both into the differences as well as the similarities between these key travel narratives of these two writers. Polish and Anglophone travel writing had been developing in clearly different ways in the nineteenth and twentieth century. In the Anglophone tradition, the genre of the travel book, after a dynamic start in the eighteenth century, was developing steadily and, for all the changes and innovations, was becoming more and more established as a genre, clearly differentiated from such (equally dynamically) evolving genres as the novel, the autobiography or the guide-book. This tradition was well known to Patrick Leigh Fermor and he fruitfully had used them in his earlier travel books: The Traveller's Tree, Mani and Roumeli. Fermor's trilogy was innovative in the sense of foregrounding the parallax metaphor, but both in its form and content it was firmly entrenched in the long established tradition of the Anglophone travel book. Whereas, in the Polish literary tradition the podróż genre, also established in the eighteenth century, disappeared, petered out in the course of the nineteenth century, as it was dynamically replaced by reportaż podróżniczy. It might be argued that this 'generic shift' was the result of the relative weakness of the book market (especially in comparison with the British and American book markets) and the growing popularity of periodicals, magazines and daily newspapers, in which Polish writers began to publish their travel accounts (often in serialized form), and the growing prestige of journalists/reporters. As I argued in "Ryszard Kapuściński: Between Polish and Anglophone Travel Writing” (Moroz 2015), Kapuściński's early books, in which he narrated his travels, all the way from Czarne gwiazdy [Black Stars] (1963) to Wojna futbolowa (The Soccer War)(1978) were reportaże podróżnicze in the strict sense of the term, relying on the tradition of reporting travel that was introduced into Polish literature by such writers as Stanisław Rejmont and developed by such established 'masters' of the genre as Ksawery Pruszyński and Melchior Wańkowicz in the period between the wars. The two books which marked a shift for Kapuściński from the journalistic, dry style of reportaż podróżniczy in the direction of a more 'literary' approach were Cesarz [The Emperor] (1978) and Szakinszach [The Shah of Shahs] (1982). As Kapuściński himself admitted, these changes were partly the result of him, as a writer, being influenced by theoretical and practical achievements of American New Journalism, which he understood as "the description of events through the application of literary tropes" (quoted in Nowacka and Ziątek 2008: 182, translation G.M.). 
In August 1980, Kapuściński, who had witnessed and reported on more than twenty revolutions in the Third World countries, was sent by Kazimierz Barcikowski, a friend of his and a Polish Communist Party Politburo member, to report on the strike in Gdańsk shipyard. Kapuściński sided with the striking workers and the nascent Solidarity movement. After the Communists fought back and declared the Martial Law on 13 December 1981, Kapuściński lost his job as a PAP correspondent and "Kultura", the weekly he had been writing for regularly, was closed for its pro-Solidarity stance. Kapuściński was given a new, unexpected lease of life, when the English translation of The Emperor was published by Harcourt Brace Jovanovich at the beginning of 1983. It received very favourable reviews in America from such influential reviewers as John Updike in the New Yorker and Peter Prescott in Newsweek. In the British Sunday Times Salman Rushdie named The Emperor his book of the year for 1983 and pronounced that Kapuściński's writing, "always wonderfully concrete and observant, conjures marvels of meanings out of minutiae. And his book transcends reportage, becoming a nightmare of power depicted as a refusal of history that reads as if Italo Calvino had re-written Machiavelli" (Rushdie 1983: 39). Such reviews meant that Kapuściński started to be regarded as a pundit on the Third World issues and a guru of reportage. He was being invited to international conferences, writers' as well as journalists' congresses and as a university lecturer. Wiktor Osiatyński, a friend of Kapuściński’s, recalled, that: "he put a lot of work and effort into his new 'life of a famous writer'. In the course of six months he polished up his English so that he could comfortably give interviews and take part in conferences and meeting with readers without needing an interpreter ... He had his teeth done ... He changed his reporter's working outfit for a jacket, and sometimes he even put on a tie." (Domosławski 2012: 292).

When Kapuściński returned to travel writing at the end of 1980s, he was a writer and not a reporter, and he was to rely on the 'parallax effect' in all his three final books: Imperium, The Shadow of the Sun and Travels with Herodotus. In all these three books the experienced narrative persona recalls the journeys undertaken over many decades, and the hiatus (parallax) created by the erudite narrator and the apprentice traveller described in the opening chapters of these books is an important rhetorical point. In all these three narratives the narrative persona of an experienced traveller, pundit, commentator is foregrounded. Therefore, I would like to disagree with Casey Blanton, who labelled Kapuściński's late travel narratives (from The Emperor to Travels with Herodotus) as 'polyphonic travels'. Blanton stated that

Kapuściński's rhetorical choice of self-effacing and polyphonic dialogues to represent a foreign culture produces a kind of narrative that can offer as its subject matter both the fragility and the power of self/ other relations. Kapuściński's strategy is to relinquish the authorative narrative vantage point traditionally occupied by a Western traveler and to offer, instead of one's narration as the dominant voice, a polyphonic group of other voices in a dialogue with the narrator. (Blanton 2014: 299).

I believe, that the term 'polyphonic' renders the narrative of The Emperor and The Shah of Shahs very accurately. However, I would not call these narratives 'travels' because there is almost no 'travelling' described in these books, and the narrator in both of them is a 'reporter', not a 'trav- 
eler'. On the other hand, in my opinion, in Imperium, The Shadow of the Sun and Travels with Herodotus Kapuściński's narrative persona becomes exactly a type of "Western traveler" with "the dominant voice", a voice which subordinates all the other voices. "The parallax effect" is central in Imperium, where it is extended from the first chapter entitled Pińsk 39 to the final paratext of an appendix entitled “Książki cytowane w 'Imperium' ("Books Quoted in Imperium”). This appendix was for some reason not translated and not placed in the English 1994 translation by Klara Glawczewska. This appendix includes sixty books in Polish, Russian, French and English; fictional and non-fictional, on Russia and the Soviet Union, on history, philosophy, sociology and literature. It is not a typical academic type of reference/bibliography, for although it is alphabetical in order as such lists are, the quotes in the text itself are not described in any academic fashion. This appendix shows the depth and width of Kapuściński's readings and his expertise as a Sovietologist, and can be seen as functioning in grave contrast (parallax) with the scene in the first chapter when Kapuściński describes how in the autumn of 1939 his hometown of Pińsk (now in Belorussia) was invaded by the Red Army, annexed to the Soviet Union and Kapuściński as a boy of seven went to school, where Russian was the language of instruction, and the only book in class was entitled "Stalin, Voprosy Leninizma" (Studies in Leninism) (Kapuściński 1998: 4).

Of the three last Kapuściński's travel narratives, the parallax in The Shadow of the Sun is the least obvious. However, this rhetorical trope is still there; four decades of Kapuściński's travels in Africa are described, starting in 1958 in Ghana and all the way to the persona's latest visit to this continent at the end of the twentieth century. Whereas, in Travels with Herodotus Kapuściński's final book, his summa as a traveller and writer, the parallax is extremely important. The book opens in the following way:

Before Herodotus sets out on his travels ascending rocky paths, sailing a ship over the seas, riding through the wilds of Asia; before he happens on mistrustful Scytians, discovers the wonders of Babylon, and plumbs the mysteries of the Nile; before he experiences a hundred different places and sees a thousand inconceivable things, he will appear for a moment in a lecture on ancient Greece, which Professor Bieżuńska-Małowist delivers twice weekly to the first-year students in Warsaw University's department of history.

He will appear and just as quickly vanish.

He will disappear so completely that now, years later, when I look through my notes from those classes, I do not find his name. There are Aeschylus and Pericles, Sappho and Socrates, Heraclitus and Plato, but no Herodotus. And yet we took such careful notes. They were our only sources of information, The war had ended six years earlier and the city lay in ruins. Libraries had gone up in flames, we had no textbooks, no books at all to speak of.

The professor has a calm, soft, even voice, Her dark, attentive eyes regard us through thick lenses with marked curiosity. Sitting at a high lectern, she has before her a hundred young people the majority of whom have no idea that Solon was great, do not know the cause of Antigone's despair and could not explain how Themistocles lured the Persians into a trap.

If truth be told, we didn't even quite knew where Greece was or, for that matter, that a contemporary country by that name had a past remarkable and extraordinary as to merit studying at university. 
We were children of war. High schools were closed during the war years, and although in the larger cities clandestine classed were occasionally convened, here, in this lecture hall, sat mostly girls and boys from remote villages and small towns, ill read, undereducated. It was 1951, University admissions were granted without entrance examinations, family provenance mattering most—in the communist state the children of workers and peasants had the best chance of getting in. (Kapuściński 2007: 4-5)

As pointed out at the beginning of this paper, 'parallax' alludes to the difference in perception of an object seen from two different angles. And that was the case with Fermor's Between Woods and Water and in The Broken Road, or Kapuściński's Imperium and The Shadow of the Sun. But in Travels with Herodotus, as is also the case of A Time of Gifts, we have three angles. Apart from the narrative persona; experienced and skilful as a writer (opening his narrative with a series of anaphors "before...", mixing past present and future tenses) and apart from Kapuściński aged nineteen, an undereducated student of history at Warsaw University diligently taking notes during the lecture on Ancient Greece, we get the third angle: that of Herodotus. Herodotus's Histories, in Gérald Genette's terms, serves as a 'hypotext' for Travels with Herodotus, which is a 'hypertext' (Genette 1997: 5). And Herodotus, from the very beginning is presented as a master traveller and a master story teller, telling his stories with compassion, empathy, wit and skill. The copy of the Polish translation of The Histories given to Kapuściński, the young reporter by his boss, becomes a talisman and its contents a yardstick to gauge the world. In the final chapter of Travels with Herodotus, entitled poetically "We Stand in Darkness, Surrounded by Light” Kapuściński tells of his trip, a short one, from the Greek isle of Kos, to the town Kapuściński insists on calling 'Halicarnassus', although (as he is reminded by a local Turkish policeman) it is called 'Bodrum' now. Halicarnassus is the birth place of Herodotus and the description of this 'in the footsteps of the master' little trip is used by Kapuściński to sum up his musings on the nature of travel and on the nature of writing. And in these musings Kapuściński's narrative persona gets skilfully and unobtrusively merged with that of Herodotus. The key features of Herodotus, the man, the historian and the story teller are also alluded to the narrative persona. Both Herodotus and Kapuściński's narrative persona are "insatiable, spongelike organisms, absorbing everything easily and just as easily parting with it" (Kapuściński 2007: 267-68), unlike the great majority of sedentary people, they are nomads, not capable to stay in one place, they "must walk (or ride) elsewhere, further away." (Kapuściński 2007: 268), "they do not grow attached to anything, do not put down deep roots" (Kapuściński 2007: 268), and they are both men of peripheries, of Halicarnassus and Pińsk respectively, little towns far away from the centres of civilization; in fact places at the borderlands of civilization, where religions, cultures, languages and races mix breeding empathy and understanding.

Kapuściński's figure of parallax in Travels with Herodotus could also be perceived in terms of hyperbole. For, it seems that in reality the parallax/hiatus he constructs between himself aged nineteen, and himself writing Travels with Herodotus was not as huge as he depicted it. In 1951 Kapuściński was not as undereducated as the opening passages quoted earlier suggest. His parents were not peasants or workers, but teachers. Although, originally from the provincial town 
of Pińsk, the family moved to Warsaw in 1945. Ryszard Kapuściński had attended one of the best secondary schools in Warsaw-gimnazjum imienia Stanisława Staszica—and in 1950 he had had his two poems published by Dziś i jutro, while another weekly called Odrodzenie, had recorded a debate on poetry held by students in which Kapuściński’s poem "Różowe jabłka" ("Pink Apples") was compared with poetry of Vladimir Mayakovsky and the canonical Polish pre-war poets (Nowacka and Ziątek 2008: 368).

Kapuściński's fluency in English, acquired in the mid-1980s, helped him not only during conferences and lectures, but also in his readings. In 1991 Kapuściński stated that "although the achievements of such writers as Bruce Chatwin, V.S. Naipaul, Paul Theroux are obvious, they had little influence on me" (Kapuściński 2008, translation G.M.). This statement was true in 1991 but this situation was to change when Kapuściński returned to travel writing and wrote three books discussed here. And it was in these three narratives when the influence of the key contemporary Anglophone travel writers became apparent. What Kapuściński took from Chatwin, Naipaul and Theroux, was the conviction that non-fictional travel writing could be very 'literary' in nature and that one of the key aspects of such 'literariness' was an erudite narrative persona employing novelistic tools and relying on various shades of intertextuality. The narrative personae of Imperium, The Shadow of the Sun and Travels with Herodotus are centres of focalization, poets and experts.

To the best of my knowledge there is no evidence that Ryszard Kapuściński read Patrick Leigh Fermor's trilogy and it seems that it was a mere coincidence that Kapuściński wrote his narratives in the manner similar to Fermor: the erudite narrative persona looks back at his younger, inexperienced self. Their narratives remain almost unique in non-fictional, referential travel writing, they rely on the type of narration typical of memoirs, with their vantage point, 'backward' recollection of memories and not on linear, chronological narration characteristic of journals, diaries and the vast majority of non-fictional travel writing.

\section{References}

Blanton, Casey. 2014. “Ryszard Kapuściński’s Polyphonic Travels”. In: Gabriel R. Ricci (ed.), Travel, Discovery, Transformation, 293-308. New Brunswick: Transaction Publishers.

Borm, Jan. 2004. "Defining Travel: On the Travel Book, Travel Writing and Terminology". In: Glenn Hooper and Tim Youngs (eds.), Perspectives on Travel Writing, 13-26. Aldershot: Ashgate. Boyle, Charles. 2016. "Allowed Fools: Notes Towards the Elizabethan Twelfth Night", http://shakespeareoxfordfellowship.org/elizabethan-twelfth-night. (accessed: 02.01.2017)

Cooper, Artemis. 2012. Patrick Leigh Fermor: An Adventure. New York: New York Review Books.

Domosławski, Artur. 2012. Ryszard Kapuściński: A Life, translated by Antonia Lloyd- Jones. London: Verso.

Fermor, Patrick Leigh. 2005. A Time of Gifts: On Foot to Constantinople: From the Hook of Holland to the Middle Danube. New York: New York Review of Books.

Fermor, Patrick Leigh. 2006. Mani: Travels In the Southern Peloponnese. New York: New York Review of Books. 
Forsdick, Charles, Feroza Basu and Siobhan Shilton. 2006. New Approaches to Twentieth-Century Travel Literature in French: Genre, History, Theory. Frankfurt am Mein: Peter Lang.

Genette, Gérarld. 1997. Palimpsests: Literature in the Second Degree. Lincoln: University of Nebraska Press.

Kapuściński, Ryszard. 1998. Imperium, translated by Klara Glowczewska. London: Granta Books. Kapuściński, Ryszard. 2007. Travels with Herodotus, translated by Klara Glowczewska, London: Penguin Books.

Kapuściński, Ryszard. 2008. Lapidaria I-III, Warszawa: Biblioteka Gazety Wyborczej.

Mastorakis, Nico. 1972. https://www.youtube.com/watch?v=_OwQoMV5ldU

Moroz, Grzegorz. 2015. Ryszard Kapuściński: Between Polish and Anglophone Travel Writing, Studies in Travel Writing, Vol. 19, Issue 2. 169-183.

Moroz, Grzegorz. 2016. “Travel Books, Nostalgia and Paratexts: The Case of Patrick Leigh Fermor's A Time of Gifts”. In: Wojciech Drąg and Ewa Kłębowska-Ławniczak (eds.), Spectrum of Emotions: From Love to Grief, 159-168. Frankfurt am Mein: Peter Lang Edition.

Nowacka, Beata and Zygmunt Ziątek. 2008. Ryszard Kapuściński: Biografia Pisarza. Kraków: Wydawnictwo Znak.

Raban, Jonathan. 1982. "Introduction" In: Alexander William Kinglake, Eothen, or Traces of Travel Brought Home from the East, i-xxii. London: Century Publishing.

Rushdie, Salman. 1983. “Christmas Books”, Sunday Times, 11 December 1983, 39.

Smith, Sidonie and Julia Watson. 2001. Reading Autobiography: A Guide for Interpreting Life Narratives. Minneapolis: University of Minnesota Press.

Witosz, Bożena. 2007. "Gatunki podróżnicze w typologicznym ujęciu genologii lingwistycznej”. In: Dariusz Rott (ed.), Wokót reportażu podróżniczego, 11-29. Katowice: Wydawnictwo Uniwersytetu Śląskiego. 